\title{
DISCIPLINE STRATEGIES PRACTISED IN EARLY CHILDHOOD SETTINGS IN MAURITIUS
}

\author{
Belle Louis Jinot ${ }^{1 \mathrm{i}}$, \\ Moraby Munirah ${ }^{2}$ \\ ${ }^{1}$ Academic Affairs Division, \\ Open University of Mauritius, \\ Reduit, Mauritius \\ ${ }^{2}$ Child Care Educator, \\ Child Development Centre, \\ Charles Telfair Institute, \\ Mauritius
}

\begin{abstract}
:
This research was conducted to identify and examine the discipline strategies that early childhood teachers may adopt to deal with disruptive behaviours of toddlers. The research was a qualitative research design and a case study. Five early childhood teachers were selected using purposive sampling and 30 toddlers in a private early childhood centre. The data about the practice of discipline strategies by the teachers were gathered by a semi-structured interview schedule and non-participant observation was used to collect data from the toddlers. According to the results of the study, it was found that early childhood education teachers were adopting positive discipline to prevent behaviour problems. The strategies adopted are guidance, autonomy, creating positive relationships, effective planning of the learning environment, and emotion coaching. This research shed light on the shift in the discipline paradigm in the early childhood setting in Mauritius. Instead of adopting reactive and punitive strategies, the practitioners are adopting proactive and discipline which is more humanistic and egalitarian, particularly when the child should be given the best learning opportunities for their holistic development. The findings may serve as an eye-opener especially for the policy and decision-makers like the Ministry of Education, to rethink the current practices in the public early childhood settings. For further research, a comparative study may be done to examine the extent to which positive discipline may be implemented in the public early childhood centres of the country.
\end{abstract}

Keywords: positive discipline, toddlers; teachers

i Correspondence: email 1.belle@open.ac.mu 


\begin{abstract}
:
Cette recherche a été menée pour identifier et examiner les stratégies disciplinaires que les enseignants de la petite enfance peuvent adopter pour faire face aux comportements perturbateurs des tout-petits. La recherche était une conception de recherche qualitative et une étude de cas. Cinq enseignants de la petite enfance ont été sélectionnés à l'aide d'un échantillonnage raisonné et 30 enfants en bas âge dans un centre privé de la petite enfance. Les données sur la pratique des stratégies disciplinaires par les enseignants ont été recueillies par un calendrier d'entretien semi-structuré et l'observation non participante a été utilisée pour recueillir des données auprès des tout-petits. D'après les résultats de l'étude, il a été constaté que les enseignants en éducation de la petite enfance adoptaient une discipline positive pour prévenir les problèmes de comportement. Les stratégies adoptées sont l'accompagnement, l'autonomie, la création de relations positives, la planification efficace de l'environnement d'apprentissage et le coaching émotionnel. Cette recherche met en lumière le changement de paradigme de la discipline dans le cadre de la petite enfance à Maurice. Au lieu d'adopter des stratégies réactives et punitives, les praticiens adoptent une discipline proactive et plus humaniste et égalitaire, en particulier lorsque l'enfant doit bénéficier des meilleures opportunités d'apprentissage pour son développement holistique. Les résultats peuvent ouvrir les yeux, en particulier pour les responsables politiques et les décideurs comme le ministère de l'Éducation, pour repenser les pratiques actuelles dans les milieux publics de la petite enfance. Pour des recherches plus poussées, une étude comparative peut être menée pour examiner dans quelle mesure une discipline positive peut être mise en œuvre dans les centres publics de la petite enfance du pays.
\end{abstract}

Mots clés: discipline positive, tout-petits; enseignants

\title{
1. Introduction
}

A toddler is a child aged between twelve months and three years. During this stage, toddlers tend to be more active and their need for energy increases significantly (Cowbrough, 2010). According to the Centres for Disease Control and Prevention (2020), in this range of age, toddlers have an increasing desire to be independent and they are very excited about doing things. They experience huge thinking, social, and emotional changes and learning that help them explore their new environments. They want to make sense of it by following two- or three-step directions, sort objects by shape and colour, imitate the actions of adults and playmates, and express a wide range of emotions. This stage is known as the 'terrible twos'. Toddlers reach the following developmental milestones, namely how they play, learn, speak, behave, and move (like crawling, walking, or jumping as well as jumping, running and balancing). Since parents are working people, they leave their toddlers in a crèche or daycare centre or a nursery. A nursery is an organisation of adults that takes care of children, usually less than eight years old, in the place of their parents (Saqib, 2008). One of the two objectives of the 
nursery is improving the child development of the toddlers (Berlinski \& Schady, 2015). Child development includes the behavioural development of the toddler.

However, it is obvious that the working mother withdraws the toddler from the family home to a new environment that may not as healthy and safe for the child. According to Saqib (2008), there are many issues in nurseries in developing countries like Mauritius and Pakistan, namely toddlers may develop at-risk behaviours if they do not receive proper nutrition, care and attention; their rights to creativity and quality child development may be violated; lack of food hygiene and a safe play area; and the caregivers (teachers) may not be professionally qualified in child care and development. Within the scope of these issues and the desire for the toddler to reach the developmental milestones, the problem of inappropriate behaviour may become a major issue of concern for the early childhood teachers. The latter have much difficulty dealing with this lack of discipline.

Lack of discipline is a complex problem in schools. Belle (2017) defined discipline as the absence of misbehaviour and the child's responsibility to make the difference between right and wrong and what is socially acceptable or not at school. Toddlers manifest their lack of discipline in the classroom in various ways, namely: excessive noncompliance, stealing, aggression, inattentiveness, cruelty, impulsivity, somatic complaints, anger, cheating, disobedience and temper tantrums (Henricsson \& Rydell, 2004; Martin, Linfoot, \& Stephenson, 2005; Pourhossein, Habibi, Ashoori, Ghanbari, Riahi \& Ghodrati, 2015, Wilton, 2020). On account of the developmental milestones that toddlers would wish to reach and the child development setting of the structured daycare centre or nursery, the learning environment may become challenging for the early childhood teacher or caregiver to manage the unacceptable behaviour of these exciting toddlers (Wilton, 2020). The current study examines the possible strategies that may be adopted by early childhood teachers to address the issue of behaviour problem.

\section{Literature review}

Since child development is an important aspect for caregivers, a theoretical background is first and foremost fundamental to better understand the perspectives for behaviour management of toddlers. A review of three contemporary models of developmental psychopathology is done in an attempt to understand the causes of disruptive behaviour in toddlers. This is essential to have knowledge for discussing the discipline strategies. The early childhood teacher should have a thorough understanding of the different learning theories to take the most appropriate disciplinary strategy to address any behaviour problem effectively. The social learning theory, the attachment theory and the self-and emotion regulation theory are discussed and analysed in this study.

The focus in the social learning theory is on ways in which the child learns from interacting with one another, by observing others, especially their teachers and peers. Besides, it blends behavioural concepts of reinforcement and punishment with cognitive concepts of awareness and expectations. Reciprocal causation between environmental conditions and cognitive variables explains how each child learns at school. Bandura's 
model of social learning theory (1986) examines how the child seizes the opportunity to model the best example of the desired behaviour. The components of observational learning or modelling that are necessary for learning to take place are attention, retention, motor reproduction, and motivation (Tennyson \& Volk, 2015). Attention establishes the role of the environment as the first source of information to be learnt. Retention evokes a cognitive condition in which the child recalls the desired behaviour. Motor reproduction requires the child to assume the necessary role conditions of the desired behaviour. Finally, reproducing observed behaviour requires the child to be motivated to do so for some reason. Dadds and Tully (2019) maintained that effective discipline should (a) reduce the likelihood of antisocial behaviour to recur; (b) model positive and calm positive interpersonal relationships; (c) strengthen an alternative positive behaviour; (d) increase self-efficacy; (e) restrict active disciplinary measures to operant child behaviour. Therefore, the learning environment and the interactions of the toddlers within it determine the latter's behaviour.

The attachment theory of Bowlby and Ainsworth hypothesised that toddlers form an internal working model of their attachment relationships, which provides the framework for their beliefs about their self-worth and how much they can depend on others to meet their needs. Studies have shown that there are many behaviours that toddlers develop in their attachment process (Kennedy \& Kennedy, 2004). The first one is secure attachment. They consider others as supportive and helpful, and consider themselves as competent and worthy of respect; so, they develop positive relationships with others and display resilience, get involved in complex play and are more successful in their interactions with the caregiver and other toddlers as they have trust. Secondly, with the anxious-avoidant attachment style, toddlers are less capable of managing stressful circumstances. They withdraw and are reluctant to seek help; so, they do not have good relationships with others. They are more aggressive and tend to manifest socially unacceptable behaviour such as bullying and lying. Besides, when they are in the anxious-resistant attachment cycle, they lack self-confidence and they want to feel close to their teachers. They socially isolate themselves and they overreact emotionally. Finally, when they are in a disorganised attachment, toddlers cannot cope with separation distress, and so they are more aggressive as they consider others as threats to their sources of support. They also isolate themselves. Dadds and Tully (2019) pointed out that, from the attachment theory perspective, an effective disciplinary strategy should provide the toddler with the message that the teacher cares about him/her, does not accept the behaviour, and believe in his/her capacity to demonstrate self-control and positive behaviour. Toddlers who lack self-confidence and trust in others may develop behaviour problems.

The third theory relevant to this study is the self-and emotion regulation theory. Emotions may direct us to say and do what is right for a situation, but some emotions like fear or anger may overwhelm the toddler (Ekman, 2003). This theory explains a relevant situation attracts the attention of the child to give rise to a situation appraisal, whereby he/she sees the novelty of the situation, its pleasantness that may either push the child towards it or avoid it, depending on its relevance to the latter (Gillespie \& Beech, 
2016). There is a shred of clear evidence that there is a connection between the parents' dysregulated parenting styles and deficits in the child's ability to regulate his/her emotions (Chang, Schwartz, Dodge \& McBride-Chang, 2003). From the perspective of the self-and emotion regulation theory, an effective discipline measure must not challenge or reduce but must enhance the child's capability to self-regulate his/her behaviour (Blewitt et al, 2020). Dadds and Tully (2019) emphasised that this can be achieved only if some form of control may be shifted from the parent to the child so that the latter may develop the skills of autonomous self-discipline. So, when the toddlers are provided with sufficient autonomy, they may become more disciplined.

In the Tuning in to Kids intervention programme carried out in Iran among fiftyfour toddlers over a period of three months, it was found that when mothers' emotional socialisation practices are changed, the disruptive behaviour problems of toddlers decrease (Meybodi, Mohammadkhani, Pourshahbaz, Dolatshahi \& Havighurst, 2017). Socialisation is influenced by the ways parents and caregivers such as early childhood teachers regulate and express their emotions; it depends on how they coach their children in regulating their emotions and how they react to their children's negative emotional expressions (Eisenberg, Cumberland \& Spinrad, 1998). In a previous study, it was also found that emotion dismissing parenting harms the emotional and behavioural development of toddlers (Duncombe, Havighurst, Holland \& Frankling, 2012). Toddlers should therefore develop the capabilities to control their emotions and understand those of others.

In a study carried out with 128 caregivers on the effect of caregivers' autonomy support on the self-regulation skills, it was found that the more autonomy support the caregivers give to the toddlers, the more the latter can develop their self-regulation skills (Meuwissen \& Carlson, 2019). Self-regulation is an important aspect of self-discipline for toddlers. Indeed, the aim of disciplining toddlers should be "the internalisation of discipline" (Jones, 1987). When there are self-esteem, emotions, relationship building and values that convey respect for the adults and peers and demonstrate caring, the toddler is likely to be disciplined (Manning \& Butcher, 2013). More autonomy support by the teachers contributes to the toddler's ability to self-regulate and thus to manage his/her behaviour positively.

Developing the social and emotional competencies of toddlers is crucial in helping the latter to more effectively adapt to the nursery environment and the early childhood educators and to manifest socially acceptable behaviour. In a study carried out among one hundred toddlers and nine preschool educators in a kindergarten, using the Developmental Evaluation Platform in Romania, it was found that when toddlers are taught socio-emotional competencies such as rule compliance, prosocial behaviour and understanding emotions, they do not manifest emotional and behavioural problems and there is lower risk of social exclusion (Moraru, Stoica, Tomuletiu \& Filpisan, 2011). In another study conducted in Malaysia among 49 toddlers using Preschool Social Emotional Competency Inventory, Im, Jiar and Talib (2019) found that a toddler with poor social and emotional competencies is likely to have behavioural problems and develop physical and mental health problems. Indeed, the positive emotional relations 
between the toddler and the caregiver have a positive effect on the behaviour of the former (Trifan, 2015). The caregiver must promote emotionally and socially secured toddler relationships. According to Trifan (2015), this can be achieved when the caregiver (a) gives special time to each toddler in the setting; (b) maintains constant attitudes towards the toddler so that the latter feels secured; (c) looks, listens and responds to the toddler by being fully attentive to him/her; (d) has realistic expectations of the toddler; and (e) has healthy relationships with the toddler's parents. Showing much attention to the toddlers is essential for them to behave well.

Besides, in a qualitative study conducted with communist members of the Chitwan District in Nepal, it was found that caregivers manage toddlers' behaviour problems by listening, talking, consoling, advising and using corporal punishment as a last resort (Adhikari, Upadhaya, Gurung, Luitel, Burkey, Kohrt \& Jordans, 2015). The findings recommended that toddler behaviour management takes place within multilevel community-based interventions which involve parents, peers, caregivers or teachers and community leaders. However, a survey carried out in the US in 2013 showed that $78 \%$ of 787 paediatricians disagreed that corporal punishment should be used to address the behaviour problems of toddlers (Taylor, Fleckman, Scholer, \& Branco, 2018). Serge and Siegal (2018) confirmed that toddlers who are spanked more than twice a month develop more aggressive behaviour at the age of five. For Gartrell (2020), the discipline of toddlers should not be considered as punishment, but rather as guidance. The two studies revealed that punitive measures do not work efficiently in addressing behaviour problems.

In a study on young children with behavioural problems in the US, it was found that 5-minute and 15-minute time-out conditions were effective behaviour modification procedures to manage non-compliant behaviour in the classroom (Fabiano et al., 2004). Time-out helps in reducing non-compliance behaviour as well as intentional aggression. However, Warzak, Floress, Kellen, Kazmerski \& Chopko (2012) reported that the effectiveness of time out depends on whether it is exclusionary or non-exclusionary. Besides, since its application in the education setting is a controversial procedure in terms of ethical considerations or legal implications, if time-out is to be used, it must be the least restrictive and the least aversive and therapeutic procedure that is applied on an individualised basis (Wolf, McLaughlin \& Williams, 2006). Time-out is not a universally accepted strategy.

From the foregoing discussion from the existing literature, it is obvious that possible appropriate discipline strategies that may be adopted by the early childhood teacher should be taken from the perspectives of the contemporary models of psychopathology and the evidence-based strategies that have been revealed in the empirical evidence. This lays the background to understand the problem of toddlers' behaviour in the Mauritian context and examine the following research question:

What are the possible discipline strategies the teacher/caregiver may adopt in the nurseries to address the behaviour problem? 


\section{Method}

\subsection{Research design}

The research design adopted to collect data for this study was the descriptive case study. The descriptive case study provides a thorough understanding of a current phenomenon of study within the context of its authentic situations (Biggam, 2011). The aim of the study was to obtain a better understanding of the natural setting in which the phenomenon of toddlers' behaviour problem occurs daily by interpreting the views and perspectives of the caregivers who are the teachers themselves dealing with such toddlers. Indeed, Kakabadse and Steane (2010) posit that a qualitative researcher attempts to define and interpret unclear phenomena through non-numerical methods of measurement that focus on meaning and insights. It allows the researchers to have new perspectives of the nature and kinds of emotional, personal and social interactions that occur among the participants of the study (Gay et al., 2011). This study is exploratory in nature.

\subsection{Research setting}

The study was carried out in a nursery, which is part of the Child Development Centre of a private higher education institution in Mauritius. For ethical considerations, the school was named, School Z. The 30 toddlers of the nursery are mostly of the teaching and non-teaching staff of the private HEI. This is a diverse staff with well-educated locals and foreigners who are lecturers in the HEI or other HEIs. The diverse context made the nursery an informative research setting for this study.

\subsection{The population and the sample}

The study population was only 5 early childhood teachers, who are the key informants about the current discipline strategies that they adopt to deal with such toddlers in their daily experiences and the social context. The sample was all 5 early childhood teachers and all the $30 \mathrm{kids}$ in the nursery section. The table below describes the profile of the sample:

Table 1: The demographic characteristics of the sample

\begin{tabular}{|c|c|c|c|c|}
\hline Teachers & Gender & Age & Qualifications & $\begin{array}{c}\text { Years of teaching } \\
\text { experience in the centre }\end{array}$ \\
\hline A & Female & 25 & $\begin{array}{c}\text { Diploma in Early } \\
\text { Childhood Education }\end{array}$ & 4 \\
\hline B & Female & 27 & $\begin{array}{c}\text { B Ed in Early } \\
\text { Childhood Education }\end{array}$ & 4 \\
\hline C & Female & 27 & $\begin{array}{c}\text { B Ed in Early } \\
\text { Childhood Education }\end{array}$ & 8 \\
\hline $\mathrm{D}$ & Female & 28 & $\begin{array}{c}\text { Diploma in Early } \\
\text { Childhood Education }\end{array}$ & 8 \\
\hline $\mathrm{E}$ & Female & 40 & $\begin{array}{c}\text { B Ed Early } \\
\text { Childhood Education }\end{array}$ & 10 \\
\hline
\end{tabular}


The purposive sampling was selected as it prevails in the phenomenological qualitative paradigm and focuses on an in-depth analysis of the specific phenomenon in a specific context.

\subsection{Data collection and analysis}

Two instruments of data collection were used, namely individual interview with the caregivers and non-participant observation by the researchers in the setting. A semistructured interview allows the researchers to explore the experiences and feelings of the participants in-depth; it allows flexibility for participants to express freely about the problem, and the structure of the interview schedule ensures the same research topic themes are discussed with all participants, and the information gathered are "raw" (Matthews \& Ross, 2010). Observation allows the researchers to gather the information from their lens and filter which focuses on the social actions, reaction and reactions of the participant in their natural setting (Saldana, 2011). They used an observation schedule to gather the information for the study.

The qualitative data were transcribed verbatim and analysed using thematic content analysis. The five steps of Yin (2011), namely compiling, disassembling, reassembling and arraying, interpreting and concluding, were followed. The researchers organised and analysed the data. The Review tools in Microsoft Word were used to highlight the relevant quotes that explained the relevant emerging themes from both the transcriptions and the observation log. The data were disassembled to identify the emerging themes and they were reassembled for interpretation and conclusions.

\subsection{Trustworthiness and transferability}

Using small sampling interview allowed the researchers to arrive at conclusions that are specific to the sample, but which gives a reflective or exploratory depth to the problem of toddlers' lack of discipline, but non-participant observation allowed them to investigate what the caregivers and the toddlers do rather than what the caregivers say they do in the interview (Davies \& Hughes, 2014). This enabled methodological triangulation to mitigate any researcher bias (Gorissen, van Bruggen \& Jochems, 2013), and ensured construct validity and reliability (Amerson, 2011). The two researchers were the observers. A pilot study was carried out prior to the actual data collection process in order to ensure the validity of the study. To ensure the trustworthiness of the qualitative data, the researchers used a self-reflective journal, in which they continuously critically reflect on themselves as, "the human, being the instruments of their own research" (Denzin \& Lincoln, 2005). Because of the sample size, there is no scope for generalisation, but the transferability of the findings is possible, depending on the comparable characteristics of other settings and the profile of the external caregivers (Lincoln \& Guba, 1985). Yet, the findings would give insights about the phenomenon of behaviour problem among toddlers to caregivers, directors of nurseries, and the educational authorities of the early childhood setting for policy-making purposes to address the current phenomenon in Mauritius. 


\subsection{Role of the researchers and the ethical considerations}

For the interview, the researchers were participant researchers and took the traditional neutral stance whereby they did not influence the participants' perceptions, thoughts, and opinions. They did not act as experts in the field of study but considered the participants as information-rich experts about the effective behaviour management of toddlers. Besides, the researchers were passive observers in the school setting. They did not assume any responsibilities in the classroom or on the school premises but instead focused on data collection (Gay et al., 2011). They were observing from a distance (Sekaran \& Bougie 2010).

The researchers spent at least fifty hours in the research centre for observation. They were the least possible intrusive for a minimum time among the toddlers and the teachers. This ensured them to be part of their actions, emotions and experiences indirectly and passively. Also, they minimised the potential risk of 'researcher bias': they bracketed their own experiences, opinions and preconceptions about the phenomenon. Moreover, the researchers opened themselves to the opinions, experiences and perspectives of the participants. This allowed them to have thick descriptions that they used as verbatim statements for analysing the data.

Permission was sought and obtained from the Director of the private higher institution, who is the gatekeeper of the research setting, to conduct the study. A consent form with all the information about the study was given to the participants who approved their participation and to the parents of the toddlers for their approval for their child's voluntary participation. The informants were given the assurance of confidentiality and anonymity; that the collected data would be used only for the purpose of this study, and that once the study is completed the data will be discarded, to ensure the privacy of data, in terms of the Mauritius Data Protection Act, 2017. The data collection procedures were based on the principle of primum non nocere, (Marshall \& Rossman, 2011), that vulnerable participants were informed of the possibility of no physical harm, emotional disturbance or physical consequences in the process.

\section{Research findings and discussion}

Toddlers are vulnerable little children who need special care and attention to grow as responsible citizens in society. They need to feel secure in the new environment of the nursery where they spend much time with the caregivers. This study attempted to investigate the caregivers' practice of addressing behaviour problems among toddlers. The themes that emerged from the interviews and the observation are developing positive relationships with toddlers; providing autonomy to them; teaching guidance and positive discipline; emotion coaching; and effective planning of the learning environment.

\subsection{Developing positive relationships with toddlers}

The findings from the study revealed that learner-centred teacher-toddler relationships that show empathy, care, warmth, trust and mutual understanding help to reduce 
disruptive behaviour in early childhood setting. The participants agreed that positive and healthy relationships with their toddlers help improve the behaviour of the latter. Teacher A highlighted this statement by pointing out:

"A good relationship with the children helps them to behave well in their surrounding and with their classmates."

The researchers observed that the children helped each other to arrange the chairs around the lunch table and the teachers usually had a friendly conversation with them, making them laugh. This illustrated the favourable classroom climate that existed in the learning environment and prevented the occurrence of behaviour problems in the setting. Indeed, such health-promoting school climate boosts self-esteem, social connectedness and, hence, reduces the occurrence of negative social behaviour among toddlers (McGrath \& Noble, 2010). It helps to promote the positive social capital of the early childhood centre.

\subsection{Providing autonomy to toddlers}

Early childhood is a phase of the toddlers' life when they desire to pursue their own needs and interests. it is at this time that their behaviour is volitional (Barrable, 2019). However, the degree of self-regulation by the toddler is largely dependent on the support provided by the socialising agent at the centre, namely the teacher (Sokol, Grouzet, Müller, Deci \& Ryan, 2013). This study showed that supporting autonomy to toddlers is an effective strategy to prevent misbehaviour. All the participants actively supported their toddlers and they considered it a way to help them develop positive discipline. Teacher C succinctly highlighted the essence of autonomy support:

"When I see my children struggling with the ability to be autonomous, I usually organize play and role activities for them to get involved and be creative and imaginative."

Barrable (2019) added that autonomy support practices also include providing time and space structures that allow toddlers to play, hide, rest, and manage potential risks while engaging and developing a sense of ownership to the school environment. By supporting the toddlers, the teachers enhance the circle of security and empower the toddlers to manage their own behaviour (Australian's Education and Care Quality Authority, 2018).

\subsection{Teaching guidance and positive behaviour}

Many external factors push toddlers to exhibit disruptive behaviour Guiding toddlers is an emancipatory approach to discipline and it is regarded as the best discipline practice that promotes positive discipline and counteracts the external factors (Porter, 2008). Four of the participants agreed that toddlers should be taught guidance. Teacher $C$ stressed:

\section{"Children should be taught how to behave in the society".}


Consistently, Teacher A concurred:

"I often integrate the teaching of important social skills in my daily curriculum so as to equip them to regulate their own behaviour in a positive way. I teach them how to solve basic life situations, how to properly communicate and how to respect their classmates and their own body."

The researchers observed some of these aspects in the daily classroom environment: some of the teachers did talk about positive discipline, like toddlers must not bite, hit classmates, and teach them the magical words like 'Thank you', 'Please', 'Good morning', 'Sorry', and 'Bye'. It is obvious that for the participants, discipline is not control, but the ability of toddlers to manage their behaviour. Millei (2011) supported the findings of this study as he maintained that democratic life skills such as respect for self and others, collaboration, problem-solving and acceptable ways of expressing emotions by giving toddlers the right to voice and choice in their interactive learning environment at schools. This approach to discipline is more humanistic and egalitarian as the toddler is considered as responsible as individuals. Positive guidance is likely to prevent challenging behaviour (Sanchez, Steece-Doran \& Jablon, 2013). Positive guidance implies the coaching by the teachers that facilitates the positive socialisation of the toddlers and hence making them more independent and reasonable in their behaviour.

\subsection{Emotion coaching}

The study showed that most of the participants have recourse to emotion coaching technique to prevent behaviour problem in nurseries. It is a universal strategy for supporting sustainable emotional and behavioural well-being within the educational setting (Gus, Rose \& Gilbert, 2015). They considered emotion coaching as very important. Teacher D convincingly voiced out:

"Emotion coaching is important where it helps the children to control their emotions and understand the emotions of their classmates."

The researchers recognised that teachers were using snapshots of expanded feelings to guide the toddlers on how to give productive responses to the manifestations of different emotions. During the emotion coaching process, the teacher's attitudes, awareness, beliefs, expressions and regulation of emotions, how they react to the toddlers' expressions and the teacher's discussion and support of the toddlers' emotions are engaged (Rose, McGuire-Snieckus \& Gilbert, 2015). The five steps to model prosocial emotional intelligence that must be used by teachers for toddlers are (a) be aware of the toddler's emotions; (b) recognise emotion as an opportunity for intimacy and teaching; (c) listening empathically and validate the toddler's feelings; (d) help the toddler verbally label the emotions; and (e) setting limits while helping the toddler solve problems (Gottman, Katz \& Hooven, 1997). This technique supports the relationships between the teacher and the toddler as well as the relationships among toddlers and therefore helps 
improve the toddlers' competencies to manage their difficult emotions and thus regulate their behaviour more successfully.

\subsection{Effective planning of the learning environment}

The learning environment of the early childhood setting is a very important characteristic of effective teaching and learning. This study revealed that planning learning spaces that would unfold the creative process of toddlers is essential in helping to prevent behaviour problems in classrooms and the centre. Creativity can only occur in an environment that promotes social learning. Four teachers agreed that effective planning of the environment ensures good behaviour among toddlers. To justify this statement, Teacher A, explicitly asserted:

"A good planning at school can prevent the children to behave differently by implementing interesting activities such as painting. Caregivers can focus on the children's interest when planning for an activity at school".

The learning environment should be stimulating, nurturing and supportive of creative spaces (Mohammed, 2018). From this perspective, Teacher C mentioned:

"For the environment, teachers should post interesting mobile for the children to give a positive environment".

This environment should create learning opportunities. From the researchers' observation, there was a behaviour chart in each classroom, and in the morning, toddlers choose an emoticon (sad, happy, annoy or angry) that they stick on the chart. Based on the emoticons chosen, the teacher starts a conversation around positive discipline with them. They even engage the toddlers in a short role-play activity in an attempt to help them develop the capacities to control their own emotions and hence behaviour. This shows that the teachers are planning the learning spaces that are within the framework of the OECD $21^{\text {st }}$ century learning approaches which foster a culture of experiment and flexibility of learning in terms of student-centeredness, transferable learning spaces, provision for children with physical, learning and behavioural difficulties as well as the use of different sources of knowledge, including digital sources (OECD, 2018).

\section{Conclusions and recommendations}

Early childhood practitioners have to be very cautious when choosing the appropriate discipline strategies. Whereas discipline as a form of control still being used in secondary schools in Mauritius (Belle, 2017), this study revealed that the disciplinary strategies adopted by the teachers are grounded in the philosophy of positive discipline which views the child from the humanistic perspective, and not from the custodial perspective (Millei, 2011). The strategies discussed in this current empirical study are more considered as guidance than as punishment. Indeed, Gartrell, (2020) stressed that 
corporal punishment makes toddlers feel harmed, hurt, rejected, angry and depressed. Guidance helps teachers build caring and strong relationship with toddlers, who develop trust and respect for the former. It is recommended that the early childhood centre sets up a whole-school based behaviour management plan that would rope in not only the teachers but also the parents, the toddlers themselves, the school head, community leaders and NGOs as well as educational psychologists, public health officers and welfare officer who work collaboratively towards creating a safe and sound learning environment for toddlers. There is a need to adopt a holistic approach as behaviour management involves socio-emotional competencies, effective leadership skills and styles that promote distributed leadership. Indeed, Darling-Hammond, Flook, CookHarvey, Barron and Osher (2019) suggested that the school head must lead the behaviour of students by understanding and building on the latter's experiences at school to strengthen the healthy development of the young students and ensure positive discipline. The school head should empower the teachers to become teacher leaders. or leaders of the leader, so that they collaborate to preventing behaviour problems among toddlers. The findings of the study shed light on the current discipline practices of teachers and it helps the stakeholders who are decision-makers to rethink the effectiveness of the actual application of behaviour modification approaches to discipline that are more reactive or punitive in public preschools, which are attached to primary schools. One of the immediate change of the government's policy should be the setting up of frequent parental conference at the national and local level, where parents are taught proactive discipline strategies so that the same methods of discipline are implemented both by the school and them. This would create a positive and strong synergy in the discipline management of toddlers who often need modelling of proper behaviour and consistency in acts to be shaped positively.

It is suggested that further studies are done on behaviour management strategies in public early childhood settings; the perceptions of parents of the prevalence of misbehaviour among toddlers at school; and a comparative study on behaviour management by using the quantitative methodology. However, this current study used a small qualitative sample, which allowed the researcher to get insights into the current discipline strategies adopted by teachers. Though the findings may be transferable, yet they cannot be generalised. The small population in the early childhood centre limited the possibility of using the mixed-methods approach.

\section{Conflict of Interest Statement}

The authors declare no conflicts of interests.

\section{About the Authors}

Dr. Belle Louis Jinot is an academic at the Open University of Mauritius. He currently serves as a lecturer and Programme Leader in the field of Educational Leadership and Management. He holds a D. Ed in Education Management. He is a Commonwealth scholar (MA Online and Distance Education from the Institute of Technology Education, The Open University, UK) and he is currently an Association of Commonwealth 
Universities Fellow in Education at Bayero University, Kano, Nigeria. His areas of interest are technology-enhanced education, educational leadership and management, school principalship. He has widely published in the field of educational management. Moraby Munirah is a Child Care Educator at the Child Development Centre, Charles Telfair Institute. She has many years of teaching experiences in the Early Childhood Settings in Mauritius.

\section{References}

Adhikari, R. P., Upadhaya, N., Gurung, D., Luitel, N. P., Burkey, M. D., Kohrt, B. A., \& Jordans, M. D. (2015). Perceived behavioural problems of school-aged children in rural Nepal. Child and Adolescent Psychiatry and Mental Health, 9(5), 1-9. Retrieved from https://capmh.biomedcentral.com/track/pdf/10.1186/s13034-015-0061-8.

Amerson, R. (2011). Making a case for the case study method. Journal of Nursing Education, 50, 427-428.

Australian's Education and Care Quality Authority. (2018). Supporting children to regulate their own behaviour. Retrieved from https://www.acecqa.gov.au/sites/default/files/202001/QA5 Supporting children to regulate their own behaviour.pdf.

Barrable, A. (2019). Shaping space and practice to support autonomy: lessons from natural settings in Scotland. Learning Environment Research. Retrieved from https://link.springer.com/article/10.1007/s10984-019-09305-x.

Belle, L. J. (2017). A critical review of the current education system of Mauritius and learner discipline problem in Mauritian state secondary schools. Journal of Social Sciences, 8(1), 47-55.

Berlinsky, S., \& Schady, N. (2015). Day Services: It is all about quality. The Early Years. Inter-American Development Bank.

Biggam, J. 2011. Succeeding with your master's dissertation: A step-by-step handbook. London: McGraw-Hill International Ltd.

Blewitt, C., Morris, H., Jackson, K., Barrett, H., Bergmeier, H., O' Connor, A., Moussa, A., Nolan, A., \& Skouteris, H. (2020). Integrating health and educational perspectives to promote preschoolers' social and emotional learning: Development of a multifaceted program using an intervention mapping approach. International Journal of Environmental Research and Public Health, 17(575), 1-24.

Centres for Disease for Control and Prevention. (2020). Child Development. National Centre on Birth Defects and Developmental Disabilities, Retrieved from https://www.cdc.gov/ncbddd/.

Chang, L., Schwartz, D., Dodge, K. A., \& McBride-Chang, C. (2003). Harsh parenting in relation to child emotion regulation and aggression. Journal of Family Psychology, $17,598-606$.

Cowbrough, K. (2010). Feeding the toddler: 12 months to 3 years - challenges and opportunities. Journal of Family Health Care, 20(2), 49-52. 
Dadds, M., \& Tully, L. (2019). What is it to discipline a child: what should it be? A reanalysis of time-out from the perspectives of child mental health, Attachment, and trauma. American Psychologist. Retrieved from https://psycnet.apa.org/doiLanding?doi=10.1037\%2Famp0000449.

Davies, M. \& Hughes, N. 2014. Doing a successful research project using qualitative or quantitative methods. London: Palgrave MacMillan.

Darling-Hammond, L., Flook, L., Cook-Harvey, C., Barron, B., \& Osher, D. (2019). Implications for the educational practice of the science of learning and development. Journal of Applied Developmental Science, 24(2), 97- 140. Retrieved from https://doi.org/10.1080/10888691.2018.1537791

Denzin, H. K. \& Lincoln, S. Y. (2005), The SAGE handbook of qualitative research, Thousand Oaks, CA: Sage Publications Inc.

Duncombe, M. E., Havighurst, S. S., Holland, K. A., \& Frankling, E. J. (2012). The contribution of parenting practices and parent emotion factors in children at risk for disruptive behaviour disorders. Child Psychiatry \& Human Development, 43(5), 715-733.

Eisenberg N., Cumberland A., \& Spinrad, T. L. (1998). Parental socialization of emotion. Psychological Inquiry, 9(4), 241-73.

Fabiano, G. A., Pelham, W. E., Manos, M. J., Gnany, E. M., Chronis, M. A., Onyango, A. N., Lopez-Williams, A., Burrows-MacLean, L., Coles, K. E., Meichenbaum, D. L., Caserta, D. A., \& Swain, S. (2004). An evaluation of three time-out procedures for children with AD/HD. Behaviour Therapy, 35(3), 449-469.

Gartrell, D. (2020). Teaching young children. National Association for the Education of Young Children, 13(3). Available at https://www.naeyc.org/resources/pubs/tyc/feb2020/using-guidance-notdiscipline

Gay, L. R., Mills, G. E. \& Airasian, P. (2011). Educational research: Competencies for analysis and applications. Upper Saddle River, NJ: Pearson.

Gillespie, S., \& Beech, A. (2016). Theories of emotion regulation, in The Wiley Handbook on the theories, assessment, and treatment of sexual offending, chapter 12, Wiley.

Gorissen, P., van Bruggen, J., \& Jochems, W. (2013). Methodological triangulation of the students' uses of recorded lectures. International Journal of Learning Technology, 8, 20-40.

Gottman, J. M., Katz, L. F., \& Hooven, C. (1997). Meta-emotion: How families communicate emotionally. Mahwah, NJ: Lawrence Erlbaum Associates.

Gus, L., Rose, J., \& Gilbert, L. (2015). Emotion coaching: A universal strategy for supporting and promoting sustainable emotional and behavioural well-being. Educational and Child Psychology, 32(1), 31-41.

Henricsson, L., \& Rydell, A. (2004). Elementary school children with behaviour problems: Teacher-child relations and self-perception. A prospective study. Merrill-Palmer Quarterly. 
HighScope Educational Research Foundation. (2015). Aligning for COR advantage with the Michigan early childhood standards of quality for infants and toddlers programmes (2013). Retrieved from www.coradvantage.org.

Jones, F. 1987. Positive classroom discipline. New York: McGraw-Hill.

Kakabadse, N. K., \& Steane, P. (2010). Meaning and interpretation: Insights and discourse. Journal of Qualitative Research in Organisations and Management: Journal of Management History, 4, 123-150.

Kennedy, J., \& Kennedy, C. (2004). Attachment theory: Implications for school psychology. Retrieved from https://onlinelibrary.wiley.com/doi/epdf/10.1002/pits.10153

Lincoln, Y. S. \& Guba, E. G. (1985). Naturalistic inquiry. Newbury Park, CA: Sage Publications.

Manning, M. L. \& Bucher, K. T. (2013). Classroom management: Models, applications and cases. Upper Saddle River, NJ: Pearson Education Inc.

Mararu, A., Stoica, M., \& Tomuletiu, A., Filipisa, M. (2011). Evaluation of a program for developing Socio-emotional competencies in preschool children. Procedia - Social and Behavioural Sciences, 30, 2161-2164. Retrieved from https://www.sciencedirect.com/science/article/pii/S1877042811022440\#!

Marshall, C. \& Rossman G. B. 2011. Designing qualitative research. London: Sage Publications, Inc.

Martin, A. J., Linfoot, K., \& Stephenson, J. (2005). Problem behaviour and associated risk factors in young children. Australian Journal of Guidance and Counselling, 15, 116.

Matthews, B. \& Ross, L. (2010). Research methods: A practical guide for the social sciences. London: Pearson Education Ltd.

McGrath, H. and Noble, T. (2010) Supporting positive pupil relationships: Research to practice in Educational and Child Psychology, 27(1) 79-90.

Meuwissen, A., \& Carlson, M. S. (2019). An experiential study of the effects of autonomy support on preschoolers' self-regulation. Journal of Applied Developmental Psychology, 60, 11-23.

Meybodi, A. F., Mohammadkhani, P., Pourshahbaz, A., Dolatshahi, B., \& Havighurst, S. (2017). Reducing children behaviour problems: A pilot study of Tuning in to Kids in Iran. Iranian Rehabilitation Journal, 15, (3), 269-276.

Millei, Z. (2011). Thinking differently about guidance: Power, children's autonomy and democratic environments. Journal of Early Childhood Research, 1-12. Retrieved from https://journals.sagepub.com/doi/abs/10.1177/1476718X11406243

Mohammed, R. (2018). Creating learning in early years: Nurturing the characteristics of creativity. NY: Routledge.

OECD. (2018). 21 ${ }^{\text {st }}$ Century Learning: Research, Innovation and Policy. OECD/CERI International Conference. Retrieved from http://www.oecd.org/site/educeri21st/40554299.pdf 
Pourhossein, R., Habibi, M., Ashoori, A., Ghanbari, N., Riahi, Y., \& Ghodrati., S. (2015). Prevalence of behavioural disorders among preschool children. Journal of Fundamentals of Mental Health, 5(5), 234-239.

Rose, J., McGuire-Snieckus, R., \& Gilbert. L. (2015). Emotion coaching: A strategy for promoting behavioural self-regulation in children/young people in schools: a pilot study. The European Journal of Social and Behavioural Sciences, 13, 1767-1790. http://dx.doi.org/10.15405/ejsbs.159

Saldana, J. 2011. Fundamentals of qualitative research: Understanding qualitative research. New York: Oxford University Press.

Sanchez, D. D., Steece-Doran, D., \& Jablon, J. (2013). Planning for positive guidance: Powerful interactions make a difference. Teaching Young Children, 6(2). https://www.naeyc.org/resources/pubs/tyc/dec2012/planning-for-positiveguidance

Saqib, A. (2008). Need Assessment Report: Creche (Daycare centre) for children of working women. Canadian International Development Agency: Pakiskan. Retrieved from https://www.ilo.org/wcmsp5/groups/public/---asia/---robangkok/---ilo-islamabad/documents/publication/wcms 122322.pdf

Sege, R. D., \& Siegel, B. S. (2018). Effective discipline to raise healthy children. Paediatrics, 142(6), 1-10. Retrieved from https://pediatrics.aappublications.org/content/142/6/e20183112

Sekaran, U. \& Bougie, R. (2010). Research methods for business. A skill-building approach. UK: John Wiley \& Sons.

Sokol, B. W., Grouzet, F. M. E., Müller, U., Deci, E. L., \& Ryan, R. M. (2013). The importance of autonomy for development and well-being. In B. W. Sokol, F. E. Grouzet, \& U. Muller (Eds.), Self-Regulation and autonomy: Social and developmental dimensions of human conduct. 19-46. Cambridge, UK: Cambridge University Press.

Taylor, C. A., Fleckman, J./ M, Scholer, S. J., Branco, N. (2018). US paediatricians' attitudes, beliefs, and perceived injunctive norms about spanking. Journal of Development Behavioural Pediatry, 39(7), 564-572.

Tennyson, R., \& Volk, A. (2015). Learning theories and educational paradigms, International Encyclopedia of the Social \& Behavioural Sciences (Second Edition), available at https://www.sciencedirect.com/topics/social-sciences/sociallearning-theory

Trifan, M. (2015). Promoting the emotional wellbeing of preschoolers. Procedia-Social and Behavioural Sciences, 209(3), 509-523.

Warzak, W. J., Floress, M. T., Kellen, M., Kazmerski, J. S., Chopko, S. (2012). Trends in time-out research: Are we focusing our efforts where our efforts are needed? The Behaviour Therapist, 35(2), 30-33.

Wilton, J. (2020). Briefing 54: Trauma, challenging behaviour and restrictive interventions in schools. Centre for Mental Health: UK. Retrieved from https://www.centreformentalhealth.org.uk/sites/default/files/202001/Briefing 54 traumainformed\%20schools 0.pdf 
Wolf, T. L., McLaughlin, T. F., \& Williams, R. L. (2006). Time-out interventions and strategies: A brief review and recommendations. International Journal of Special Education, 21(3), 22-29. Retrieved from https://files.eric.ed.gov/fulltext/EJ843616.pdf

Yin, R. K. (2011). Qualitative Research from start to finish. Guilford Press: New York. 
Creative Commons licensing terms

Author(s) will retain the copyright of their published articles agreeing that a Creative Commons Attribution 4.0 International License (CC BY 4.0) terms will be applied to their work. Under the terms of this license, no permission is required from the author(s) or publisher for members of the community to copy, distribute, transmit or adapt the article content, providing a proper, prominent and unambiguous attribution to the authors in a manner that makes clear that the materials are being reused under permission of a Creative Commons License. Views, opinions and conclusions expressed in this research article are views, opinions and conclusions of the author(s). Open Access Publishing Group and European Journal of Education Studies shall not be responsible or answerable for any loss, damage or liability caused in relation to/arising out of conflicts of interest, copyright violations and inappropriate or inaccurate use of any kind content related or integrated into the research work. All the published works are meeting the Open Access Publishing requirements and can be freely accessed, shared, modified, distributed and used in educational, commercial and non-commercial purposes under a Creative Commons Attribution 4.0 International License (CC BY 4.0). 